\title{
Destination Information Sources for Itinerant Holidaymakers: A Study of Island Hoppers in Greece
}

\author{
By Jens Kr. Steen Jacobsen*
}

This article explores information sources for destination decision-making in the underresearched context of mobile tourism with a quite low level of pre-tour decisions. The questionnaire-based study attends to this gap through updated documentation of vacationer use of online networking sites, review sites, and other information sources. The results show that conventional word-of-mouth was still decisive for destination choices in this context of island hopping in the Aegean, Greece. Websites with traveller evaluations proved more popular than guidebooks, indicative of the advance of usergenerated content (eWOM). Nevertheless, guidebooks were nearly as important as review sites, contrasting several studies and indicative of a continued or renewed guidebook interest. Despite some earlier assertions, there were only small differences in employment of internet-based information sources between younger "digital natives" and older "digital immigrants". Information conveyed through social networking sites was of little importance for destination decision-making for these tourists, contradicting some of the literature. Particularly to attract younger holidaymakers and first-time visitors, destination marketing organisations might encourage more vacationers to post photographs and videos on the internet (visual eWOM).

Keywords: Information source, destination decision-making, internet use, Web 2.0, social media.

\section{Introduction}

Advances of social networking sites, tourist blogs, travel review sites, and tourism enterprises' websites indicate that tourist use of information sources may be transformed. This is particularly related to technologies that afford global reach of content (Qualman 2009). In addition, more prevalent smartphone and tablet computer use may have bearings on tourist information availability and acquisition (Wang et al. 2016). While much research during the first decades of the twentyfirst century has concentrated on tourist use of online content, it is ever more pertinent to study holidaymaker use also of various other destination information sources in specific contexts.

The present study aimed at compensating for the dearth of empirical academic research on mobile tourists without their own vehicles/vessels and with a generally quite low level of pre-tour decisions and bookings. Such vacationers are typically hard to capture in customary surveys and data collection methods as their numbers tend to be too small for meaningful analyses. The article provides updated evidence on the subjectively perceived importance of several long-established

${ }^{*}$ Professor, University of Stavanger, Norway. 
and newer information sources for holiday destination decision-making and it explores patterns of information source use. The research is based on an en route questionnaire survey of international summer holidaymakers visiting Greek Aegean islands.

\section{Literature Review}

Most people take in external information prior to selecting their holiday destination(s) (Hyde 2008). Such travel decisions have commonly been influenced by positive and negative word-of-mouth: verbal person-to-person communication (Arndt 1967, Dann 1996, Fodness and Murray 1998). For services, personal information sources have often been preferred to impersonal sources (Murray 1991). It has been assumed that electronic word-of-mouth (eWOM), influencing others via the internet (Negroponte and Maes 1996), will become more prevalent in tourist decision-making during the first decades of the twenty-first century (Kim et al. 2015, Litvin et al. 2008). Still, research on influence of eWOM sources on destination choice is scarce (Tham et al. 2013). Some eWOM sources (blogs, social networking sites and user-generated information on media sharing sites and review sites) may be termed "personal" although identity cues vary (Baym 2010). While traditional word-of-mouth is mainly one-to-one or few-to-few, electronic word-of-mouth may have a very wide reach and a high diffusion speed (Hays et al. 2013, Qualman 2009). Popular types of social media include wikis (e.g., Wikitravel), blogs (e.g., Travelblog) and microblogs (e.g., Twitter), social networking sites (e.g., Facebook), media sharing sites (e.g., Instagram, Flickr, YouTube), and review sites (e.g., TripAdvisor) (Zarrella 2010). Travel blogs have presumably grown in popularity (Mack et al. 2008).

In the early stage of the World Wide Web, most people looked into content on fixed sites, what has been termed "Web 1.0" (Cormode and Krishnamurthy 2008). Second-generation or Web 2.0 internet sites use more sophisticated technology, enabling two-way communication and user-generated content (Zarrella 2010). It has been alleged that second-generation websites (Web 2.0) founded on interactive solutions and user participation will affect holidaymakers' information search more than previously (Fortezza and Pencarelli 2015, Gretzel and Yoo 2008). Based on these and other changes, it has been assumed that usergenerated internet content will have a greater bearing on destination choices (Tussyadiah and Fesenmaier 2009). Still, a Dutch study has indicated that not much information for vacation decision-making has been transferred via online social networking sites such as Facebook (Bronner and de Hoog 2014). Moreover, Bronner and de Hoog (2016) have also noted an advance of travel information sites with commercial interests and a stagnation in the use and trustworthiness of sites with traveller generated reviews and with no commercial interests, what has been perceived as "wisdom of the crowd" (Surowiecki 2004).

A study of Anglophone users of the review site TripAdvisor disclosed that one out of four respondents rated other travellers' online reviews as important sources for their destination decision (Gretzel and Yoo 2008). Additionally, 
persons who are interconnected through social networking sites have been found to make more intense use of information from the Web for travel bookings (Morrison et al. 2001). It has also been suggested that younger travellers, as "digital natives" (those born after 1980) (Prensky 2001), will make more thorough use of internet-based information (Ip et al. 2010). For instance, a study conducted between 2007 and 2012 in the United States has shown that nearly one in three members of Generation X (born between 1965 and 1980) and of Generation Y (born between 1981 and 1995) relied solely on the internet for travel planning (Kim et al. 2015). Somewhat similarly, a study conducted in Denmark in 2010 revealed that travellers born after 1975 made much more use of review sites (e.g. TripAdvisor) than did respondents born in 1975 or earlier (Jensen and Hjalager 2013). Then again, it has been maintained that people's attitudes may often matter more than their age (Munar 2012).

Destination information is also available from seemingly independent or impartial sources such as travel guidebooks (Dann 1996, Heimtun and Jacobsen 2012) and newspapers and magazines (Morosan 2015). Guidebooks are typically used by quite individualistic tourists (Zillinger 2006), although guidebook users' independence may vary (Caruanaet al. 2008). In the United States, younger members of Generation Y have made less use of guidebooks for travel planning than have older travellers (Kim et al. 2015), while Danes between 18 and 34 years of age made more use of such travel books than did Danes 35 and older (Jensen and Hjalager 2013). A study conducted in the United States between 2007 and 2012 found a generally low level of guidebook use (Xiang et al. 2015). While guidebook sales plummeted some years after the turn of the century, there was again considerable growth in several guidebook markets from 2014 (Mesquita 2016).

Although many tourists have become more independent of intermediaries, various travel agencies and tour operators still influence destination decisionmaking (Jensen and Hjalager 2013, Munar and Jacobsen 2013). Individual holidaymakers seem generally more experienced than travellers who buy package tours (Lauring 2013) and may rely less on industry and mainstream sources of information (Ioannides and Debbage 1997). Still, it has been upheld that vacationers who do not use package tours might be more dependent on information about their destination (Osti et al. 2009).

Research on tourists' information sources regarding destination familiarity has shown mixed results (Jacobsen and Munar 2012, Kerstetter and Cho 2004). Some studies have found that traveller use of external information decreased as destination familiarity increased; other studies have concluded the opposite. Baloglu (2001) disclosed that first- time visitors to a destination tended to use commercial information sources; repeat visitors used both commercial and noncommercial sources. Moreover, Milman and Pizam (1995) and Gursoy (2003) found that travellers who were familiar with a destination used more external information sources than newcomers did. Conversely, a later study concluded that people who had been to a place before invested less effort in researching it (Carneiro and Crompton 2010). Carneiro and Crompton (2010) also discovered 
that people who resided farther away from a destination were more likely to search for information than were people who lived closer to it.

Nonetheless, there is a dearth of updated empirical evidence of the possible changing importance of information sources for destination choice and a gap in the understanding of possible advances of electronic word-of-mouth (Chiang et al. 2014, Luo and Zhong 2015) and potential retreat in analogue sources. Factors that may influence changes include more use of smartphones (Wang et al. 2016) and tablet computers, cheaper and faster mobile telephone networks and more wireless internet connection zones (see Lamsfus et al. 2015). Furthermore, there is a need to examine leisure travellers' information source accentuation in specific empirical contexts, such as types of holidays and destinations. It was thus decided to study island hoppers' information sources for their destination choices. Based on the foregoing literature review, the following questions were formulated:

Is conventional word-of-mouth still of importance to destination decisionmaking in this context of mobile holidaymaking?

To what degree is there still use of guidebooks, and what is their present-day standing versus digital information sources?

Have Web 1.0 websites been surpassed by Web 2.0 sites for destination information?

Do younger tourists make more thorough use of internet-based networks than older tourists do?

Is there more intense use of Web information sources among tourists linked through social networking sites than among other tourists?

Do tourists who purchase a tour package emphasise fewer information sources than do non-package (independent) tourists?

Are there differences between first-time visitors and repeaters in how they emphasise destination information sources?

Is there more emphasis on several information sources among visitors from farther away than among tourists from nearby countries?

\section{Methodology}

\section{Sample}

Island hoppers with a generally quite low level of pre-tour decisions and bookings were chosen as respondents for this study. Most foreign summer holidaymakers in seaside Greece travel to larger islands with an international airport and substantial accommodation capacity (SETE 2013), often using package tours. Conversely, most leisure travellers leaving Greece from Athens airport are independent travellers (Theofanides and Karagiannopoulou 2013). Thus, visitors to selected Cycladic islands southeast of Athens were considered suitable for this study, as most of them island-hop and travel via Athens. Data were collected from non-Greek leisure travellers departing on selected ferries and catamarans from the islands of Naxos, Folégandros, Amorgós, and Thera. The 
study concentrated on the early part of the peak summer season because improvised or serendipitous island hopping is much easier and thus more common at this time of the year than in late July and in August, when it can be arduous to find lodging on short notice. The scheduling was based on earlier visits to these ports at various times.

Prospective respondents waiting in the ports were asked to fill in selfcompletion questionnaires, which were returned to the survey staff. As numbers of international tourists on the selected departures were not available, the response rate was not known. The reply rate among those who were asked to fill in the questionnaires was calculated to be slightly over $60 \%$. This was considered acceptable, as quite similar air travel surveys have typically had response rates between $20 \%$ and $40 \%$ (Hurst 1994). A total of 539 valid questionnaires was included in the sample.

Table 1. Key Sample Features

\begin{tabular}{|c|c|c|c|}
\hline & Percentages & Frequencies & $\begin{array}{c}\mathrm{N} \\
\text { (total }=539)\end{array}$ \\
\hline \multicolumn{4}{|l|}{ Gender } \\
\hline Female & 57 & 304 & \\
\hline Male & 43 & 233 & 537 \\
\hline \multicolumn{4}{|l|}{ Educational level } \\
\hline Primary school & 4 & 22 & \\
\hline Secondary education & 20 & 107 & \\
\hline University/college & 76 & 407 & 536 \\
\hline \multicolumn{4}{|l|}{ Age, years } \\
\hline Up to 31 & 32 & 146 & \\
\hline 32 or older & 68 & 315 & 461 \\
\hline \multicolumn{4}{|l|}{ Residence region } \\
\hline European countries & 80 & 430 & \\
\hline Countries outside of Europe & 20 & 109 & 539 \\
\hline \multicolumn{4}{|l|}{ Duration of stay in Greece } \\
\hline Up to one week & 6 & 34 & \\
\hline $8-14$ days & 56 & 302 & \\
\hline More than two weeks & 38 & 202 & 538 \\
\hline \multicolumn{4}{|l|}{ Experience with the Cyclades } \\
\hline First visit & 42 & 225 & \\
\hline Once before & 15 & 79 & \\
\hline Twice or more before & 44 & 234 & 538 \\
\hline \multicolumn{4}{|c|}{$\begin{array}{l}\text { Number of Greek islands visited (including present } \\
\text { trip) }\end{array}$} \\
\hline One to five & 59 & 317 & \\
\hline Six to ten & 20 & 108 & \\
\hline More than ten & 21 & 111 & 536 \\
\hline \multicolumn{4}{|l|}{ Journey organisation type } \\
\hline Bought only air ticket & 68 & 358 & \\
\hline Bought air ticket and accommodation, etc. & 33 & 172 & 530 \\
\hline \multicolumn{4}{|l|}{ Facebook membership } \\
\hline Yes & 69 & 370 & \\
\hline No & 31 & 163 & 533 \\
\hline
\end{tabular}


Table 1 presents central sample features. Some $38 \%$ would stay more than two weeks in Greece. Some $42 \%$ of the respondents were first-time visitors to the Cyclades, $15 \%$ had visited once before, and $44 \%$ had been to these islands two or more times before. Two-thirds had bought only an air ticket while one-third had purchased some kind of tour package combining an air ticket and (some) accommodation. The purchase of tour packages was at approximately the same level for first-timers and the others. Moreover, two out of three tourists had Facebook membership, the prevalent social networking site at the time of the survey. As many as $76 \%$ of the respondents had college or university education, compared to $29 \%$ in a study of British first-time visitors in the Greek island of Corfu (Kerkyra) (Vitouladiti 2013) and a European Union average of 28\% among 25 to 64 years-olds in 2011 (Corner 2015).

\section{Measurement}

The main objective was to provide empirical evidence of island hoppers' self-reported use of selected electronic and other information sources for their destination choices. Responses on the subjective importance of destination information sources were given on a five-point Likert-type scale ranging from zero ("unimportant") to four ("very important"). The following sources were included: "own experience", "information through Facebook", "information from acquaintances/family other than through Facebook", "websites with guest evaluations (TripAdvisor, Booking.com, etc.)", "hotel/apartment websites", "reports in newspapers, magazines, radio, television", "airline websites", "tour operator/ travel agency websites", "guidebooks", "websites of tourism organisations in Greece", "tourist photos/videos on the internet", "tourist blogs (not acquaintances)", and "microblogs". The survey thus comprised internet information sources that were considered among the most vital for destination choice in similar contexts and included Web 1.0 and Web 2.0 platform sources.

Additionally, the holidaymakers were asked about their familiarity with the destination area (the Cyclades archipelago) and whether they had purchased a tour package. Moreover, the study elicited common demographic variables such as gender, year of birth, and country of residence (divided between Europeans and non-Europeans). The interview situation presupposed that the questions were simple enough to answer within a few minutes.

To reveal possible associations between continuous outcome variables (mean scores) and categorical determining variables, independent samples $t$-test was utilised. Only differences that were statistically significant at the $0.05 \%$ level $(p<0.05)$ were reported.

\section{Results}

The most important destination information sources for these island hoppers in the Cyclades were own experience, information from acquaintances/family (other than through Facebook), websites with guest evaluations such as TripAdvisor 
and Booking.com, and guidebooks. At least half of the respondents found these four sources to be important (Table 2). Of somewhat lesser importance were hotel/ apartment websites, tourist photos/ videos on the internet (visual eWOM), news media reports, tourist blogs, and websites of tourism organisations in Greece, underscored by between $43 \%$ and $23 \%$ of the respondents. Of even less importance were tour operator/travel agency websites and airline websites, underlined by $15 \%$ and $13 \%$ respectively. Information gleaned from social networking sites (e.g. Facebook) and microblogs were least important, emphasised by only $4 \%$ and $2 \%$ of the interviewees, respectively.

Table 2. Importance of Tourist Information Sources for Decision to Travel to Greece, Percentages and Mean Scores (scale 0-4)

\begin{tabular}{|l|c|c|c|c|c|c|c|c|}
\hline & Unimportant & & $\begin{array}{c}\text { Neither/ } \\
\text { nor } \\
(2)\end{array}$ & $(1)$ & $\begin{array}{c}\text { Very } \\
\text { important } \\
(4)\end{array}$ & $\begin{array}{c}\text { Mean } \\
\text { score }\end{array}$ & SD & $N$ \\
\hline Own experience & 11 & 5 & 13 & 23 & 48 & 2.9 & 1.35 & 527 \\
\hline $\begin{array}{l}\text { Acquaintances/family } \\
\text { (not through Facebook) }\end{array}$ & 15 & 9 & 17 & 31 & 28 & 2.5 & 1.38 & 523 \\
\hline Websites with guest evaluations & 26 & 9 & 15 & 25 & 26 & 2.2 & 1.55 & 520 \\
\hline Guidebooks & 25 & 10 & 16 & 31 & 19 & 2.1 & 1.46 & 528 \\
\hline Hotel/apartment websites & 34 & 10 & 14 & 26 & 16 & 1.8 & 1.53 & 523 \\
\hline Tourist photos/videos on the internet & 34 & 13 & 22 & 24 & 7 & 1.6 & 1.35 & 525 \\
\hline Newspapers, magazines, TV, radio & 36 & 17 & 24 & 19 & 5 & 1.4 & 1.28 & 527 \\
\hline Tourist blogs (not acquaintances) & 43 & 11 & 18 & 22 & 6 & 1.4 & 1.39 & 520 \\
\hline $\begin{array}{l}\text { Websites of tourism organisations in } \\
\text { Greece }\end{array}$ & 45 & 14 & 18 & 16 & 6 & 1.3 & 1.35 & 512 \\
\hline Tour operator/travel agency websites & 59 & 12 & 14 & 10 & 5 & 0.9 & 1.28 & 521 \\
\hline Airline websites & 57 & 14 & 16 & 8 & 5 & 0.9 & 1.23 & 516 \\
\hline Information through Facebook & 70 & 12 & 14 & 3 & 1 & 0.5 & 0.90 & 519 \\
\hline Microblogs (Twitter etc.) & 76 & 9 & 13 & 2 & - & 0.4 & 0.81 & 513 \\
\hline
\end{tabular}

Repeat visitors emphasised their own experience much more than did firsttimers. Conversely, holidaymakers who had not previously visited the Cyclades rated several information sources for destination choice as more important than did repeaters: information passed on directly from acquaintances/family, websites with guest evaluations, tourist photos/videos on the internet, tourist blogs (not acquaintances), and information conveyed through Facebook. Interviewees who had purchased a tour package placed more weight on their own experience and were most likely to value the following sources: websites with guest evaluations, hotel/apartment websites, websites of tourism organisations in Greece, tour operator/travel agency websites, and tourist photos/videos posted on the internet.

There were also several differences in the value placed on information sources, between holidaymakers who did and did not have a Facebook profile. Facebook users placed less weight on their own experience while they found several sources to be more important than did non-Facebook users: information directly from acquaintances/family, websites with guest evaluations, tourist photos/videos on the internet, tourist blogs (not acquaintances), Facebook, and microblogs.

Younger "digital natives" and older "digital immigrants" differed somewhat in their assessments of information sources. Tourists older than 32 years of age 
could draw more on their own experiences and were more likely to value information found on hotel/apartment websites and on websites of tourism organisations in Greece. Visitors younger than 32 years of age considered direct word-of-mouth (from acquaintances/family), tourist photos/videos on the internet, and tourist blogs to be more important than the older holidaymakers did. There were no significant differences between the younger and older travellers in their rating of importance of information from websites with guest evaluations, guidebooks, tour operator/travel agency websites, airline websites, information through Facebook, and microblogs (Table 3).

Table 3. Importance of Tourist Information Sources for Decision to Travel to Greece, Mean Scores (Scale 0-4) by Experience with the Cycladic Islands, Purchase of Package Tour or Not, Facebook Membership, Age, and Area of Residence

\begin{tabular}{|c|c|c|c|c|c|c|c|c|c|c|c|}
\hline & \multicolumn{2}{|c|}{$\begin{array}{l}\text { Destination } \\
\text { experience }\end{array}$} & \multicolumn{2}{|c|}{$\begin{array}{c}\text { Travel } \\
\text { organisation }\end{array}$} & \multicolumn{2}{|c|}{$\begin{array}{l}\text { Facebook } \\
\text { membership }\end{array}$} & \multicolumn{2}{|c|}{$\begin{array}{l}\text { Age, } \\
\text { years }\end{array}$} & \multicolumn{2}{|c|}{$\begin{array}{c}\text { Residence } \\
\text { area }\end{array}$} & \\
\hline & $\begin{array}{l}\text { First } \\
\text { time }\end{array}$ & $\begin{array}{l}\text { Been } \\
\text { before }\end{array}$ & $\begin{array}{l}\text { Only } \\
\text { ticket }\end{array}$ & $\begin{array}{c}\text { Package } \\
\text { tour }\end{array}$ & $\begin{array}{l}\text { Face- } \\
\text { book }\end{array}$ & $\begin{array}{l}\text { No } \\
\text { FB }\end{array}$ & - & $33-$ & Europe & Other & All \\
\hline Own experience & 2.1 & $3.5 *$ & 3.0 & $2.8^{*}$ & 2.8 & $3.2 *$ & 2.5 & $3.1^{*}$ & 3.0 & $2.5^{*}$ & 2.9 \\
\hline $\begin{array}{l}\text { Acquaintances/family } \\
\text { (not through Facebook) }\end{array}$ & 2.9 & $2.2^{*}$ & 2.5 & 2.4 & 2.7 & $2.1^{*}$ & 3.0 & $2.3^{*}$ & 2.4 & $2.9^{*}$ & 2.5 \\
\hline $\begin{array}{l}\text { Websites with guest } \\
\text { evaluations }\end{array}$ & 2.4 & $2.0^{*}$ & 2.1 & $2.4^{*}$ & 2.3 & $1.9^{*}$ & 2.2 & 2.2 & 2.1 & $2.6^{*}$ & 2.2 \\
\hline Guideb & 2.2 & 2.0 & 2.1 & 2.1 & 2.0 & 2.2 & 2.0 & 2.2 & 2.1 & 2.2 & 2.1 \\
\hline Hotel/apartı & 1.8 & 1.9 & 1.7 & $2.2^{*}$ & 1.8 & 1.9 & 1.5 & $2.0^{*}$ & 1.8 & 2.0 & 1.8 \\
\hline $\begin{array}{l}\text { Tourist photos/videos on } \\
\text { the internet }\end{array}$ & 2.0 & $1.3^{*}$ & 1.5 & $1.8^{*}$ & 1.7 & $1.3^{*}$ & 1.9 & $1.4^{*}$ & 1.4 & $2.1^{*}$ & 1.6 \\
\hline $\begin{array}{l}\text { Newspapers, magazines, } \\
\text { TV, radio }\end{array}$ & 1.5 & 1.4 & 1.5 & 1.3 & 1.4 & 1.4 & 1.4 & 1.4 & 1.5 & 1.3 & 1.4 \\
\hline $\begin{array}{l}\text { Tourist blogs (not } \\
\text { acquaintances) }\end{array}$ & 1.6 & $1.2 *$ & 1.4 & 1.5 & 1.6 & $1.0 *$ & 1.7 & $1.2 *$ & 1.3 & $1.8^{*}$ & 1.4 \\
\hline $\begin{array}{l}\text { Websites of tourism } \\
\text { organisations in Greece }\end{array}$ & 1.2 & 1.3 & 1.1 & $1.5^{*}$ & 1.3 & 1.2 & 1.0 & $1.4^{*}$ & 1.3 & 1.3 & 1.3 \\
\hline $\begin{array}{l}\text { Tour operator/travel } \\
\text { agency websites }\end{array}$ & 0.9 & 0.9 & 0.7 & $1.4^{*}$ & 0.9 & 1.0 & 0.8 & 0.9 & 0.9 & 0.8 & 0.9 \\
\hline Airline websites & 0.8 & 1.0 & 0.9 & 0.9 & 1.0 & 0.8 & 0.9 & 0.9 & 0.9 & 0.7 & 0.9 \\
\hline $\begin{array}{l}\text { Information through } \\
\text { Facebook }\end{array}$ & 0.6 & $0.4^{*}$ & 0.5 & 0.6 & 0.7 & $0.2^{*}$ & 0.6 & 0.5 & 0.5 & $0.7 *$ & 0.5 \\
\hline Microblogs/Twitter & 0.5 & 0.4 & 0.4 & 0.5 & 0.5 & $0.3^{*}$ & 0.5 & 0.4 & 0.4 & $0.6^{*}$ & 0.4 \\
\hline
\end{tabular}

Note: $*$ Statistically significant difference calculated by independent samples $t$-test $(p<0.05)$.

Holidaymakers from other European countries rated their own experience as more important for destination decision-making than did the non-Europeans. Moreover, visitors from countries outside of Europe placed more emphasis than the Europeans on direct word-of-mouth, websites with guest evaluations, tourist photos/videos on the internet, tourist blogs, information through Facebook, and microblogs. 


\section{Discussion and Conclusions}

The present study propounds several contributions to academic research including noteworthy associations between vital socio-demographic variables and information sources for holiday destination decision-making in the underresearched context of mobile tourism with a fairly low level of pre-tour decisions. In a situation with more tourist destination information available on the internet and assumingly weakened positions for non-digital media, it is vital to apprehend the heterogeneity of information sourcing and possible changes in relative strength of various sources also in contexts with resourceful and mobile vacationers.

Particularly, this research provided new evidence related to mixed insights about the relative positions of digital versus analogue information sources. Despite high levels of internet use and Facebook membership among these island hoppers, conventional word-of-mouth was still decisive for destination choice. This corroborated some studies (Fodness and Murray 1997, Jensen and Hjalager 2013, Murray 1991) but was partly in opposition to the results of Kim et al. (2015), who found a totality of internet sources to be prevailing. The results here indicate that although social status and self-esteem motivations seem to drive copious tourist information dispersal (Jensen and Hjalager 2013), information received through social networking sites like Facebook will not necessarily be much considered for destination choices (Bronner and de Hoog 2014).

Review sites (with guest evaluations) proved slightly more popular than guidebooks and other websites, indicative of the recent advance of user-generated content (eWOM), corroborating Kim et al. (2015), Tussyadiah and Fesenmaier (2009), and Litvin et al. (2008). These results moderately contrasted Bronner and de Hoog's (2016) findings, that sites with user-generated reviews have been losing ground to marketer-generated sites. This might possibly be related to the mostly rather small destinations called on by these island hoppers, and thus a quite small number of destination services and attributes. The low importance of destination information from tour operator/travel agency websites seemed mainly to result from the minority of tourists who had purchased some kind of tour package.

Travel guidebooks were rated here among the four most important types of information sources, nearly in line with review sites, indicating a continued or renewed standing for analogue guidebooks compared with other sources (Mesquita 2016), contrasting some recent studies (Jensen and Hjalager 2013, Xiang et al. 2015). The results underscored a sustained emphasis on presumably autonomous information (Dann 1996, Zillinger 2006), not only guidebooks but also reports in newspapers and magazines, partly consistent with a continued print media influence disclosed by Morosan (2015). Additionally, a lesser importance of guidebooks among "digital natives" was not found here, contrasting the results of Kim et al. (2015) and possibly related to differences between North America and Europe, for instance more language variations and language barriers in Europe.

Younger tourists made partly more thorough use of internet-based networks, corresponding somewhat to Ip et al. (2010) and moderately contrasting Munar's (2012) assumption; that people's attitudes often matter more than their age. Moreover, travellers linked through social networking sites (e.g. Facebook) made 
more intense use of the Web, in line with the predictions of Morrison et al. (2001). Still, destination information conveyed through social networking sites was important only to a very small proportion of the island hoppers, deviating from the results of Kim et al. (2015) in their study in the United States of traveller sources for general trip planning.

Island hoppers who had purchased a tour package emphasised several information sources more that did those who organised their trip themselves, contrasting the indications of Osti et al. (2009). First-timers considered some sources to be more important than did repeaters, consistent with Carneiro and Crompton (2010) and inconsistent with Milman and Pizam (1995) and Gursoy (2003). These results also contradicted Baloglu (2001), as new arrivals did not differ from repeaters in the importance they placed on commercial information sources. It was also shown that tourists from farther away (non-European countries) considered several information sources more important for their destination decision-making than did European visitors, supporting Carneiro and Crompton (2010).

Taken together, this study has uniquely exhibited mobile holidaymakers' use of traditional and novel sources of information for destination decisionmaking in the context of island hopping with mostly limited pre-planned travel organisation. Although several internet sources have become significant for travel planning, the results indicated a continued strong position for traditional word-ofmouth and some analogue and presumably independent destination information sources. The article has contributed to academic literature by providing updated findings on generally highly educated and mobile tourists' appraisals of information sources in relation to variables such as destination area familiarity, membership in social networking sites, age, travel organisation, and distance to the area they called on.

Against the background of increasingly available internet-based destination information, the findings are not only interesting but also useful. Understanding information sources for itinerary decision-making can contribute to more advanced destination communication strategies. The study has given important knowledge on which tourism enterprises and destination marketing organisations can contemplate their promotion and advertising. Specifically, understanding information source patterns is relevant to destination promoters and marketers in the context of roaming holidaymakers visiting numerous places. For instance, the results indicated that new arrivals might be attracted by both traditional and electronic word-of-mouth but not much through social networking sites such as Facebook and similar. Particularly to attract younger holidaymakers and firsttime visitors, destination marketing organisations might encourage more visitors to post photographs and videos on the internet (i.e. visual eWOM), both through websites with guest evaluations and via other channels. 


\section{Limitations and Future Research}

Although being quite descriptive, this study affords a basis for future research, which might include more information sources, for instance when it comes to various types of user-generated content. Moreover, one could study the perceived credibility of different review sites, blogs and social networking sites for destination decision-making. Forthcoming studies could also explore possible changes related to generations versus age. One might ask if younger generations presage the future or if they just are different because of their age. With the expansion of destination-relevant information conveyed through the internet, the relative importance of information sources may change but some traditional sources may also be revitalised, partly because of increasing doubt that travel review sites represent "wisdom of the crowd" (Bronner and de Hoog 2016). It might also be fruitful to conduct comparable surveys in other areas with such mobile and quite highly educated holiday visitors.

\section{Acknowledgment}

The author thanks Berit Grue and Thea S. Skogheim for data preparation and adaptation.

\section{References}

Arndt J (1967) Role of product-related conversations in the diffusion of a new product. Journal of Marketing Research 4 (3): 291-295. doi:10.2307/3149462.

Baloglu S (2001) Image variations of Turkey by familiarity index: informational and experiential dimensions. Tourism Management 22: 127-133. doi:10.1016/S02615177(00)00049-2.

Baym NK (2010) Personal Connections in the Digital Age. Cambridge: Polity.

Bronner F, de Hoog R (2014) Social media and consumer choice. International Journal of Market Research 56(1): 51-71. doi:10.2501/IJMR-2013-053.

Bronner F, de Hoog R (2016) Travel websites: changing visits, evaluations and posts. Annals of Tourism Research 57: 94-112. doi:10.1016/j.annals.2015.12.012.

Carneiro MJ, Crompton JL (2010) The influence of involvement, familiarity, and constraints on the search for information about destinations. Journal of Travel Research 49(4): 451-470. doi:10.1177/0047287509346798.

Caruana R, Crane A, Fitchett JA (2008) Paradoxes of consumer independence: a critical discourse analysis of the independent traveller. Marketing Theory 8: 253-272. doi:10.1177/1470593108093556.

Chiang L, Manthiou A, Tang L, Shin J, Morrison A (2014) A comparative study of generational preferences for trip-planning resources: a case study of international tourists to Shanghai. Journal of Quality Assurance in Hospitality \& Tourism 15(1): 78-99. doi:10.1080/1528008X.2014.855536.

Cormode G, Krishnamurthy B (2008) Key differences between Web 1.0 and Web 2.0. First Monday 13(6). Retrieved from https://bit.ly/1PsD3Az.

Corner T (2015) Education in the European Union. London: Bloomsbury. 
Dann GMS (1996) The Language of Tourism: A Sociolinguistic Perspective. Wallingford: CAB International.

Fodness D, Murray B (1997) Tourist information search. Annals of Tourism Research 24: 503-523. doi=10.1016/S0160-7383(97)00009-1

Fodness D, Murray B (1998) A typology of tourist information search strategies. Journal of Travel Research 37: 108-119. doi:10.1177/004728759803700202.

Fortezza F, Pencarelli T (2015) Potentialities of Web 2.0 and new challenges for destinations: insights from Italy. Anatolia: An International Journal of Tourism and Hospitality Research 26(4): 563-573. doi:10.1080/13032917.2015.1040813.

Gretzel U, Yoo K-H (2008) Use and impact of online travel reviews. In P O'Connor, $\mathrm{W}$ Höpken, U Gretzel (eds) Information and Communication Technologies in Tourism, 35-46. Vienna: Springer.

Gursoy D (2003) Prior product knowledge and its influence on the traveler's information search behavior. Journal of Hospitality \& Leisure Marketing 10(3-4): 113-131. doi:10.1300/J150v10n03_07.

Hays S, Page SJ, Buhalis D (2013) Social media as a destination marketing tool: its use by national tourism organisations. Current Issues in Tourism 16: 211-239. doi:10.1080/13683500.2012.662215.

Heimtun B, Jacobsen JKS (2012) Guidebooks as destination image formation agents. In T Furunes, RJ Mykletun, E Marnburg (eds) Current Research in Hospitality and Tourism, 271-287. Bergen: Fagbokforlaget.

Hurst F (1994) En route surveys. In JRB Ritchie, CR Goeldner (eds) Travel, Tourism, and Hospitality Research, 453-472. New York: Wiley.

Hyde KF (2008) Information processing and touring planning theory. Annals of Tourism Research 35: 712-731. doi:10.1016/j.annals.2008.05.001.

Ioannides D, Debbage K (1997) Post-fordism and flexibility: the travel industry polygot. Tourism Management 18: 229-241. doi:10.1016/S0261-5177(97)00019-8.

Ip C, Lee HE, Law R (2010) Profiling the users of travel websites for planning and online experience sharing. Journal of Hospitality \& Tourism Research 35: 418-426. doi:10.1177/1096348010388663.

Jacobsen JKS, Munar AM (2012) Tourist information search and destination choice in a digital age. Tourism Management Perspectives 1: 39-47. doi:10.1016/j.tmp.2011. 12.005 .

Jensen JM, Hjalager A-M (2013) The role of demographics and travel motivation in travellers' use of the internet before, during, and after a trip. International Journal of Tourism Policy 5(1-2): 34-58. doi:10.1504/IJTP.2013.054051.

Kerstetter D, Cho M-H (2004) Prior knowledge, credibility and information search. Annals of Tourism Research 31: 961-985. doi:10.1016/j.annals.2004.04.002.

Kim H, Xiang Z, Fesenmaier DR (2015) Use of the Internet for trip planning: a generational analysis. Journal of Travel \& Tourism Marketing 32: 276-289. doi:10. 1080/10548408.2014.896765.

Lamsfus C, Wang D, Alzua-Sorzabal A, Xiang Z (2015) Going mobile: defining context for on-the-go travelers. Journal of Travel Research 54: 691-701. doi:10.1177/00 47287514538839.

Lauring J (2013) Creating the tourist product in the opposition between self-actualization and collective consumption. Journal of Hospitality \& Tourism Research 37: 217-236. doi:10.1177/1096348011425495.

Litvin SW, Goldsmith RE, Pan B (2008) Electronic word-of-mouth in hospitality and tourism management. Tourism Management 29: 458-468. doi:10.1016/j.tourman. 2007.05.011. 
Luo Q, Zhong D (2015) Using social network analysis to explain communication characteristics of travel-related electronic word-of-mouth on social networking sites. Tourism Management 46: 274-282. doi:10.1016/j.tourman.2014.07.007.

Mack RW, Blose JE, Pan B (2008) Believe it or not: credibility of blogs in tourism. Journal of Vacation Marketing 14: 133-144. doi:10.1177/1356766707087521.

Mesquita S (2016) Travel Publishing Year Book 2016. Surrey: Nielsen BookScan.

Milman A, Pizam A (1995) The role of awareness and familiarity with a destination: the Central Florida case. Journal of Travel Research 33(3): 21-27. doi:10.1177/ 004728759503300304.

Morosan C (2015) The influence of DMO advertising on specific destination visitation behaviors. Journal of Hospitality Marketing \& Management 24(1): 47-75. doi:10. 1080/19368623.2014.891962.

Morrison AM, Jing S, O'Leary JT, Cai LA (2001) Predicting usage of the Internet for travel bookings: an exploratory study. Information Technology \& Tourism 4: 1530. doi:10.3727/109830501108750868.

Munar AM (2012) Social media strategies and destination management. Scandinavian Journal of Hospitality and Tourism 12: 101-120. doi:10.1080/15022250.2012.67 9047.

Munar AM, Jacobsen JKS (2013) Trust and involvement in tourism social media and web-based travel information sources. Scandinavian Journal of Hospitality and Tourism 13: 1-19. doi:10.1080/15022250.2013.764511.

Murray KB (1991) A test of services marketing theory: consumer information acquisition activities. Journal of Marketing 55: 10-25. doi:10.2307/1252200.

Negroponte N, Maes P (1996) Electronic Word of Mouth. Wired 4.10 (October).

Osti L, Turner LW, King B (2009) Cultural differences in travel guidebooks information search. Journal of Vacation Marketing 15: 63-78. doi:10.1177/1356766708098172.

Prensky M (2001) Digital natives, digital immigrants part 1. On the Horizon 9(5): 1-6.

Qualman E (2009) Socialnomics: How Social Media Transforms The Way we live and do Business. Hoboken, NJ: Wiley.

SETE - Association of Greek Tourism Enterprises (2013) International tourist arrivals at the main airports, Jan-Dec 2013/2012, provisional data. Retrieved from http:// sete.gr/EN/TOURISM/Statistics/Statistics\%20categories/index.php?filter_date=2 013\&catID $=47 \&$ langID $=1 \&$ search $=1$, accessed 30 November 2015.

Surowiecki J (2004) The Wisdom of Crowds: Why the Many are Smarter than the Few and How Collective Wisdom Shapes Business, Economies, Societies, and Nations. London: Little, Brown.

Tham A, Croy G, Mair J (2013) Social media in destination choice: distinctive electronic word-of-mouth dimensions. Journal of Travel \& Tourism Marketing 30 (1/2): 144155. doi:10.1080/10548408.2013.751272.

Theofanides F, Karagiannopoulou A (2013) Exploring the touristic image of Greece. Social Science Research Network (SSRN). Retrieved from https://bit.ly/2pZabrP. [Accessed 10 December 2015].

Tussyadiah I, Fesenmaier DR (2009) Mediating tourist experiences: access to places via shared videos. Annals of Tourism Research 36: 24-40. doi:10.1016/j.annals.2008. 10.001 .

Vitouladiti O (2013) The influence of media, internet and information sources on buying decision process and destination choice: the case of an established Mediterranean destination. Proceedings of the $5^{\text {th }}$ International Conference: The Economies of Balkan and Eastern Europe Countries in the Changed World, Istanbul 9-12 May.

Wang D, Xiang Z, Fesenmaier DR (2016) Smartphone use in everyday life and travel. Journal of Travel Research 55: 52-63. doi:10.1177/0047287514535847. 
Xiang Z, Wang D, O'Leary JT, Fesenmaier DR (2015) Adapting to the Internet: trends in travelers' use of the Web for trip planning. Journal of Travel Research 54(4): 511-527. doi:10.1177/0047287514522883.

Zarrella D (2010) The Social Media Marketing Book. Farnham: O'Reilly.

Zillinger M (2006) The importance of guidebooks for the choice of tourist sites. Scandinavian Journal of Hospitality and Tourism 6: 229-247. doi:10.1080/1502225060 0869427. 